\title{
PERBANDINGAN PENGARUH EKSTRAK LIDAH BUAYA (ALOE VERA) DAN EKSTRAK DAUN SIRIH (PIPER BETLE LINN) TERHADAP KUALITAS PRODUK HAND SOAP
}

\section{COMPARISON OF THE EFFECT OF ALOE VERA EXTRACT (ALOE VERA) AND BETEL LEAF EXTRACT (PIPER BETLE LINN) ON THE QUALITY OF PRODUCTS HAND SOAP}

\author{
Annisa Zikri Robbia*, Yahdi dan Yuli Kusuma Dewi \\ Program Studi Tadris Kimia Fakultas Tarbiyah dan Keguruan UIN Mataram, Mataram, Indonesia \\ *Email: annisaziie@gmail.com
}

Diterima: 27 Januari 2021. Disetujui: 7 Februari 2021. Dipublikasikan: 3 Maret 2021

\begin{abstract}
Abstrak: Dalam pembuatan sabun cuci tangan biasanya memanfaatkan ekstrak alami yang dapat membunuh bakteri. Salah satu bahan alam yang biasa dijumpai adalah Lidah buaya (Aloe Vera) dan daun sirih (Piper betle Linn) yang memiliki banyak khasiat. Tujuan penelitian ini adalah untuk melihat kualitas Hand Soap baik dari ekstrak lidah buaya maupun ekstrak daun sirih. Analisis data menggunakan One-way ANOVA (Analysis of Varians) pada taraf 5\%. Percobaan penelitian ini menggunakan 3 sampel yaitu Hand Soap tanpa ekstrak (sebagai kontrol), Hand Soap ekstrak lidah buaya (Aloe vera) dan Hand Soap ekstrak daun sirih (Piper betle Linn). Parameter kualitas yang diamati adalah uji organoleptik, $\mathrm{pH}$, viskositas, antibakteri, dan daya busa. Hasil penelitian menunjukkan bahwa kualitas Hand Soap ekstrak daun sirih memenuhi standar SNI dengan rata-rata uji organoleptik 3,87; pH 8,23; viskositas 20486,17 cPs; daya antibakteri $13.97 \mathrm{~mm}$; dan daya busa 27,75 mm, sedangkan pada Hand Soap ekstrak lidah buaya juga memenuhi standar SNI dengan skor uji organoleptik sebesar 4,20; pH 8,68; daya antibakteri 9,12 $\mathrm{mm}$; dan daya busa 27,50 mm. Berdasarkan uji statistik dan uji lanjut BNT disimpulkan bahwa terdapat perbedaan yang signifikan pada penambahan ekstrak daun sirih dan ekstrak lidah buaya terhadap kualitas Hand soap pada parameter $\mathrm{pH}$, viskositas, dan daya antibakteri, dimana ekstrak daun sirih memiliki pengaruh paling baik terhadap kualitas Hand Soap dibandingkan dengan Hand soap kontrol dan Hand soap ekstrak lidah buaya.
\end{abstract}

Kata Kunci: Sabun cair, ekstrak lidah buaya (Aloe vera), ekstrak daun sirih (Piper betle Linn)

\begin{abstract}
In making hand soap, natural extracts are usually used which can kill bacteria. One of the natural ingredients commonly found is Aloe vera and Piper betle Linn which have many properties. The purpose of this study was toquality of determine the Hand Soap both from aloe vera extract and betel leaf extract. Data analysis used One-way ANOVA (Analysis of Variance) at the 5\% level. This research experiment used 3 samples, namely Hand Soap without extract (as control), Hand Soap extract of Aloe vera and Hand Soap extract of Piper betle Linn. The quality parameters observed were the organoleptic test, $\mathrm{pH}$, viscosity, antibacterial, and foam power. The results showed that the quality of Hand Soap betel leaf extract met SNI standards with an average organoleptic test of 3.87; $\mathrm{pH} 8.23$; viscosity $20486.17 \mathrm{cPs}$; antibacterial power $13.97 \mathrm{~mm}$; and foam power of $27.75 \mathrm{~mm}$, while the Hand Soap Aloe vera extractalso met SNI standards with an organoleptic test score of 4.20; $\mathrm{pH} 8.68 ; 9.12 \mathrm{~mm}$ antibacterial power; and foam power of $27.50 \mathrm{~mm}$. Based on statistical tests and further tests of BNT, it was concluded that there was a significant difference in the addition of betel leaf extract and aloe vera extract to the quality of hand soap on $\mathrm{pH}$, viscosity dan antibacterial parameters, where betel leaf extract had the best effect on the quality of hand soap compared to control hand soap and aloe vera extract hand soap.
\end{abstract}

Keywords: Hand Soap, Aloe vera extract, Piper betle Linn extract.

\section{PENDAHULUAN}

Dalam beraktivitas tangan sering kali terkontaminasi oleh mikroba yang menyebabkan tangan menjadi perantara masuknya mikroba ke dalam tubuh manusia bersamaan dengan makanan yang masuk dalam tubuh. Masuknya mikroba tersebut menyebabkan gangguan saluran pencernaan. Tangan penuh dengan berbagai macam kuman dan bakteri yang berdampak pada penyakit infeksi jika masuk ke dalam tubuh. Ribuan mikroba dapat menempel dan masuk kedalam tubuh melalui tangan yang masuk kedalam mulut bersama ma- kanan. Salah satu bakteri yang dapat ditemukan tersebar di alam sekitar dan paling banyak hidup di tangan adalah bakteri Escherichia coli.

Escherichia coli merupakan salah satu bakteri gram negative yang menyebabkan infeksi saluran pencernaan selain vibrio cholera dan rotavirus. Bakteri ini bertransmisi melalui jalur fekal-oral disebabkan karena rendahnya kualitas kebersihan konsumen [1]. Escherichia coli biasanya tersebar melalui tangan ketika makanan maupun minuman yang akan dimasukkan ke mulut. Escherichia coli adalah parasit yang ada dalam 
saluran pencernaan manusia dan hewan yang dapat menyebabkan penyakit peritonitis, cistitis, enteritis, dan sebagainya. Bakteri dapat mempengaruhi keadaan lingkungannya, salah satunya menyebabkan demam akibat terinfeksi oleh bakteri Escherichia coli yang terdapat pada saluran pencernaan dan menyebabkan diare [2].

Untuk mengatasi semua penyakit tersebut maka perlu dengan mencuci tangan menggunakan sabun. Dalam mensintesis sabun yang ramah lingkungan adalah dengan menggunakan tumbuhtumbuhan seperti lidah buaya (Aloe vera) dan daun sirih (Piper betle Linn). Lidah buaya (Aloe vera) dan daun sirih (Piper betle Linn) mengandung senyawa-senyawa yang memiliki aktivitas antibakteri.

Lidah buaya (Aloe vera) termasuk kedalam family Lily (Liliaceae). Tanaman ini biasanya digunakan dalam tujuan medis tradisional di beberapa budaya selama ribuan tahun. Secara in vitro, ekstrak lidah buaya dapat merangsang proliferasi beberapa jenis sel. Gel lidah buaya dan ekstraknya dikenal sebagai penyembuh luka yang lebih cepat karena memiliki efek antibakteri [3]. Efek antibakteri lidah buaya disebabkan karena terdapat komponen bioaktif dalam ekstrak lidah buaya [4]. Lidah buaya (Aloe vera) mengandung Saponin, Sterol, Acemannan, Antrakuinon [5].

Daun sirih (Piper betle Linn) merupakan salah satu tumbuhan yang dimanfaatkan sebagai pengobatan, seperti sariawan, antibatuk, astringent, dan antiseptik. Tanaman ini mengandung saponin, flavonoid, polifenol, dan minyak atsiri. Senyawa saponin bekerja sebagai antibakteri. Senyawa tersebut akan merusak membran sitoplasma dan membunuh sel. Sedangkan senyawa flavonoid diduga memiliki mekanisme kerja mendenaturasi protein sel bakteri dan merusak membran yang tidak dapat diperbaiki lagi. Didalam ekstrak daun sirih (Piper betle Linn) terdapat senyawa antibakteri seperti fenol dan turunannya yang mampu menghambat pertumbuhan kuman atau bakteri [6]. Menurut penelitian Suwondo et al, sediaan perasaan, infus, ekstrak air-alkohol, ekstrak heksan, ekstrak kloroform maupun ekstrak etanol yang terdapat dari daun sirih memiliki aktivitas antibakteri terhadap gingivitis, plak dan karies [7].

Dalam penelitian ini bertujuan untuk melihat kualitas Hand Soap baik dari ekstrak lidah buaya (Aloe vera) maupun ekstrak daun sirih (Piper betle Linn).

\section{METODE PENELITIAN}

\section{Alat dan Bahan}

Alat yang digunakan adalah timbangan, tabung reaksi, gelas kimia, stopwatch, neraca digital Kern, pH meter Hanna, viscometer Ostwald.

Bahan yang digunakan adalah Texapon (SLS), Sodium sulfat (Merck), Aquades, Metain
(Merck), Glucotain, Triclosan, Asam Etilen Diamin Tetraasetat (EDTA), Pewangi, Pewarna, LABS, Soda ash, Escherichia Coli, Aloe vera, dan Piper betle $\mathrm{L}$, kertas saring.

\section{Prosedur}

1. Pembuatan Hand Soap

Disiapkan wadah sebagai tempat pencampuran bahan-bahan. Dicampurkan Sodium Lauryl Sulfat (SLS) kedalam wadah sebanyak 150 gram dan Sodium Sulfat kedalam wadah sebanyak 90 gram. Dipisahkan setengah Sodium Sulfat kedalam wadah kosong. Ditambahkan air sedikit demi sedikit kedalam wadah sebanyak $900 \mathrm{ml}$ hingga campuran mengental. Ditambahkan metain kedalam campuran sebanyak $30 \mathrm{ml}$. Dimasukkan glucotain kedalam wadah sebanyak $9 \mathrm{ml}$. Ditambahkan pewangi dan pewarna kedalam wadah sebanyak $15 \mathrm{ml}$. Ditambahkan air sedikit demi sedikit kedalam wadah sebanyak 300 ml. Ditambahkan triclosan sebanyak 15 $\mathrm{ml}$ dan EDTA sebanyak 6 gram diaduk hingga rata. Dimasukkan 30 gram sisa sodium sulfat yang sudah dipisahkan tadi, kemudian aduk hingga mengental. Lalu didiamkan hingga campuran menjadi bening. Dituang campuran tersebut masing-masing $500 \mathrm{ml}$ ke dalam wadah kosong (larutan A, B, dan C) [8].

2. Pembuatan Ekstrak Daun Sirih

Dicuci bersih daun sirih, kemudian dikeringkan. Dipotong-potong daun sirih dan dihancurkan blender. Ditimbang daun sirih sebanyak 50 gram kemudian ditambahkan aquadest panas $100 \mathrm{ml}$, lalu dipanaskan diatas penangas air selama 60 menit pada suhu $60^{\circ} \mathrm{C}$. Didiamkan ekstrak selama 10 menit dan disaring dengan kertas saring [7].

3. Pembuatan ekstrak lidah buaya (Aloe vera) Kulit lidah buaya disayat, daging dan gel dari lidah buaya dihancurkan dengan blender. Ditimbang lidah buaya sebanyak 50 gram dan ditambahkan aquadest panas sebanyak $100 \mathrm{ml}$ lalu dipanaskan diatas penangas air selama 60 menit pada suhu $60^{\circ} \mathrm{C}$. Diamkan ekstrak selama 10 menit, selanjutnya disaring ekstrak menggunakan kertas saring [9].

4. Penyiapan Hand Soap

Ekstrak lidah buaya (Aloe vera) dicampurkan kedalam Hand Soap (larutan A) sampai tercampur rata. Ekstrak daun sirih (Piper betle Linn.) dicampurkan kedalam Hand Soap (larutan B) sampai tercampur rata. Untuk larutan $\mathrm{C}$ digunakan sebagai kontrol. 
5. Uji Organoleptik

Diberikan sampel langsung kepada 20 orang panelis dengan parameter penilaian warna, bentuk, wangi, dan tekstur dari Hand Soap.

6. Uji pH

Uji pH pada sampel dilakukan dengan menggunakan alat berupa $\mathrm{pH}$ meter.

7. Uji Viskositas

Sampel diukur dengan menggunakan viskometer.

8. Uji Antibakteri

Pengujian ini menggunakan metode difusi agar dengan kertas cakram (paper disc) yang berdiameter $6 \mathrm{~mm}$ dengan bakteri uji Echerichia coli. Kertas cakram dicelupkan ke dalam sampel kemudian diletakkan di atas media MHA yang sudah diinokulasikan dengan bakteri uji. Dilakukan inkubasi pada suhu $37^{\circ} \mathrm{C}$ selama 2 x 24 jam. Diamati terbentuknya zona bening yang berada di sekitar paper disc [10].
9. Uji Daya Busa

Disiapkan tabung reaksi. Dimasukkan sabun kedalam tabung reaksi. Dimasukkan aquadest, kemudian dikocok dengan cara membolak balikkan tabung reaksi. Diukur tinggi busa yang dihasilkan [11].

\section{HASIL DAN PEMBAHASAN}

Pembuatan sabun secara kimia dilakukan melalui reaksi penyabunan atau reaksi saponifikasi. Pada proses reaksi ini, asam lemak akan terhidrolisasi oleh basa yang membentuk gliserin dan sabun mentah [12]. Dalam pembuatan Hand Soap ini dilakukan uji organoleptik, $\mathrm{pH}$, viskositas, antibakteri, dan daya busa.

Uji organoleptik bertujuan untuk menilai mutu produk berdasarkan panca indera manusia yang meliputi warna, bentuk, wangi, dan tekstur. Uji organoleptik dilakukan untuk mengetahui kesan ketika pemakaian dan kesan setelah pemakaian produk [13]. Dari hasil pengujian Hand Soap ini didapatkan hasil skor yang cukup baik (skor 3) dan baik (skor 4) terhadap keempat parameter. Hasil penelitian ini sesuai dengan standar yang telah ditetapkan oleh SNI, yaitu warna dan wangi yang khas, sabun yang berbentuk cairan, dan teksturnya yang kental.

\section{Uji Organoleptik}

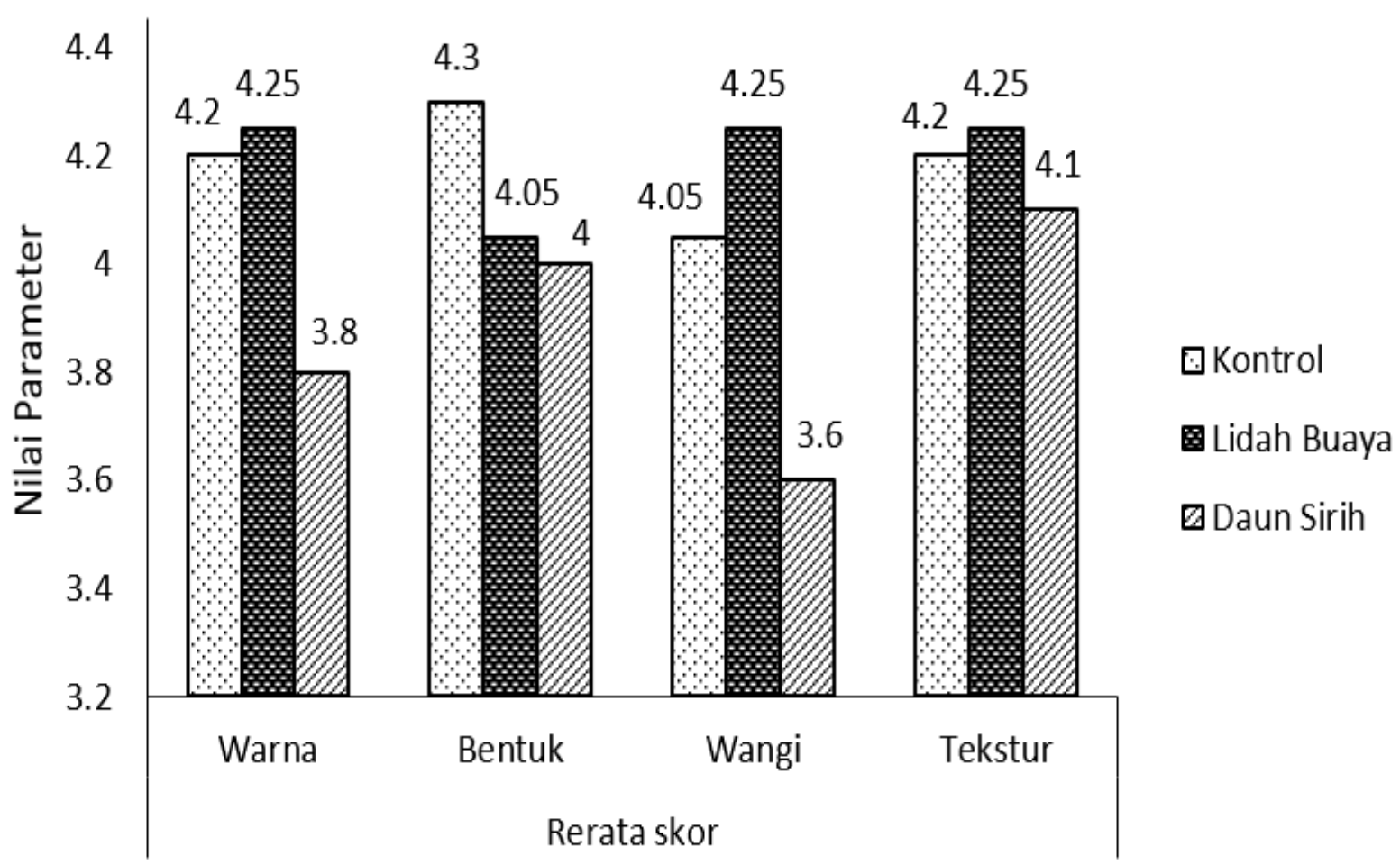

Gambar 1. Parameter Organoleptik 
Hasil uji statistik pada parameter organoleptik secara keseluruhan menunjukkan tidak adanya perbedaan pengaruh yang signifikan pada penambahan esktrak terhadap kualitas Hand soap, yang mungkin saja disebabkan karena uji organoleptik didasarkan pada panca indrawi dan selera pribadi panelis. Dari hasil uji organoleptik dapat diketahui bahwa Hand Soap dengan ekstrak lidah buaya (Aloe vera) paling banyak disukai oleh panelis dengan skor rerata 4.2, baik dilihat dari warna, bentuk, wangi maupun tekstur dari produk tersebut.

Uji $\mathrm{pH}$ bertujuan untuk melihat derajat keasaman sabun cair, ketika sabun cair mengenai kulit secara langsung dan apabila $\mathrm{pH}$ dari sabun cair tidak sesuai dengan $\mathrm{pH}$ pada kulit maka akan menimbulkan masalah pada kulit [14]. Didalam SNI sabun cair pembersih tangan, $\mathrm{pH}$ sabun cuci tangan cair berkisar antara 4-10. Adapun hasil yang didapatkan yaitu hasil semua produk memenuhi SNI.

Tabel 1. Hasil rata-rata $\mathrm{pH}$ (Hand Soap)

\begin{tabular}{|c|c|c|c|c|}
\hline \multicolumn{2}{|c|}{ Hand Soap } & Kontrol & $\begin{array}{l}\text { Lidah } \\
\text { Buaya }\end{array}$ & $\begin{array}{l}\text { Daun } \\
\text { Sirih }\end{array}$ \\
\hline \multirow{4}{*}{ 풀 } & U1 & 8.98 & 8.68 & 8.09 \\
\hline & $\mathrm{U} 2$ & 9.12 & 8.78 & 8.08 \\
\hline & U3 & 36.36 & 8.50 & 8.08 \\
\hline & U4 & 9.12 & 8.78 & 8.70 \\
\hline \multicolumn{2}{|c|}{ Total } & 36,36 & 34,74 & 32,95 \\
\hline \multicolumn{2}{|c|}{ Rerata } & $9.09^{c}$ & $8.68^{b}$ & $8.23^{\mathrm{a}}$ \\
\hline
\end{tabular}

*a-c Superscript huruf yang berbeda menunjukkan perbedaan nyata $(\mathrm{P}<0.05)$ dengan uji lanjut BNT

Rata-rata $\mathrm{pH}$ yang didapatkan pada masing-masing Hand Soap dapat dilihat pada tabel 1. Pada Hand Soap kontrol didapatkan pH 9.09, Hand Soap ekstrak lidah buaya (Aloe vera) dengan $\mathrm{pH}$ 8.68, dan Hand Soap ekstrak daun sirih (Piper betle Linn) dengan $\mathrm{pH}$ 8.23. Hasil pengukuran menunjukkan bahwa pada sabun cair yang dihasilkan memiliki $\mathrm{pH}$ basa. $\mathrm{pH}$ seluruh Hand Soap yang didapatkan sesuai dengan SNI yaitu $\mathrm{pH}$ 4-10. Produk sabun cair (Hand Soap) memiliki pH yang cenderung basa. Hal ini disebabkan karena bahan dasar dari penyusunnya yaitu Kalium Hidroksisa yang berfungsi untuk menghasilkan reaksi saponifikasi dengan lemak maupun detergen sintetis yang memiliki nilai $\mathrm{pH}$ di atas $\mathrm{pH}$ netral.

Adapun hasil analisa statistik perhitungan anova $\mathrm{pH}$ sabun didapatkan bahwa Signifikansi $<0.05(0.001<0.05)$, maka terdapat perbedaan yang nyata pada pengaruh ekstrak lidah buaya dan ekstrak daun sirih terhadap kualitas Hand Soap yang dihasilkan.

Hasil uji lanjut BNT menunjukkan bahwa terdapat perbedaan pengaruh secara signifikan, baik itu antara Hand Soap kontrol dengan Hand
Soap lidah buaya, Hand Soap kontrol dengan Hand Soap daun sirih, maupun Hand Soap lidah buaya dengan Hand Soap daun sirih.

Uji viskositas (kekentalan) merupakan uji untuk mengukur tingkat kekentalan suatu produk. Pada uji kekentalan disini digunakan alat berupa viscometer. Benda yang bergerak relatif terhadap benda yang lainnya akan mengalami gesekan. Sebuah benda yang bergerak di dalam fluida juga akan mengalami gesekan karena sifat viskositas fluida tersebut [15].

Tabel 2. Hasil rata-rata viskositas (Hand Soap)

\begin{tabular}{|c|c|c|c|c|}
\hline \multicolumn{2}{|c|}{ Hand Soap } & Kontrol & $\begin{array}{l}\text { Lidah } \\
\text { Buaya }\end{array}$ & $\begin{array}{l}\text { Daun } \\
\text { Sirih }\end{array}$ \\
\hline \multirow{4}{*}{ 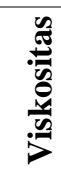 } & U1 & 283.30 & 210.50 & 243.38 \\
\hline & U2 & 254.89 & 222.39 & 200.33 \\
\hline & U3 & 242.34 & 229.76 & 177.66 \\
\hline & U4 & 230.85 & 218.69 & 198.07 \\
\hline \multicolumn{2}{|c|}{ Total } & 1011.39 & 881.35 & 819.44 \\
\hline \multicolumn{2}{|c|}{ Rerata } & $252.84^{b}$ & $220.33^{\mathrm{a}, \mathrm{b}}$ & $204.86^{\mathrm{a}}$ \\
\hline
\end{tabular}

*a-c Superscript huruf yang berbeda menunjukkan perbedaan nyata $(\mathrm{P}<0.05)$ dengan uji lanjut BNT

Adapun hasil yang didapatkan dari perhitungan viskositas menggunakan viskometer tersebut harus memenuhi SNI. Dari perhitungan viskositas dapat dilihat pada tabel 2 didapatkan bahwa Hand Soap kontrol memiliki viskositas sebesar 252.84 Poise atau 25284.8 cPs. Hand Soap ekstrak lidah buaya (Aloe vera) memiliki viskositas sebesar 220.33 Poise atau $22033.95 \mathrm{cPs}$, sedangkan Hand Soap dengan ekstrak daun sirih (Piper betle Linn) memiliki viskositas yaitu sebesar 204.86 Poise atau 20486.17 cPs. Hand Soap yang memenuhi SNI adalah Hand Soap ekstrak daun sirih (Piper betle Linn). Sesuai dengan SNI syarat dari viskositas sabun cair yaitu 500-20.000 cPs.

Adapun hasil analisa statistik perhitungan anova viskositas sabun didapatkan bahwa Signifikansi $<0.05 \quad(0.029<0.05)$, maka terdapat perbedaan yang nyata pada pengaruh ekstrak lidah buaya dan ekstrak daun sirih terhadap kualitas Hand Soap yang dihasilkan.

Hasil uji lanjut BNT, didapatkan bahwa terdapat perbedaan pengaruh secara signifikan pada Hand Soap kontrol dengan Hand Soap daun sirih pada parameter viskositasnya. Hal ini dikarenakan Hand Soap kontrol tanpa penambahan ekstrak, sehingga kekentalan pada Hand Soap kontrol lebih tinggi dibanding Hand Soap dengan penambahan ekstrak daun sirih yang membuat kekentalan pada Hand Soap daun sirih menurun. Dalam pembuatan sabun, garam dari asam stearat memiliki peran dalam memberikan konsistensi kekerasan yang ada pada sabun dan juga dapat menstabilkan busa yang akan mempengaruhi viskositasnya. Semakin 
banyak asam stearate yang digunakan maka akan semakin tinggi nilai viskositasnya.

Zat yang biasanya digunakan sebagai pengental yaitu garam elektrolit, salah satunya natrium klorida $(\mathrm{NaCl})$. Semakin tinggi konsentrasi garamnya maka viskositas juga akan meningkat, tetapi dapat juga terjadi penurunan viskositas dengan konsentrasi garam yang terlalu tinggi, karena terlalu berlebihnya konsentrasi garam dalam suatu sediaan tersebut menyebabkan garam ini menjadi jenuh. Hal ini dikarenakan beberapa dari sistem koloid dapat membentuk gel dengan penambahan ion-ion logam. Penambahan garam akan mengalami penurunan kekentalan apabila kekentalan telah mencapai titik maksimumnya. [16].

Di dalam pengujian antibakteri digunakan metode difusi agar untuk mengukur seberapa besar zona hambatan yang akan terbentuk. Pengujian ini dilakukan dengan menggunakan paper disk atau kertas cakram. Zona hambatan sendiri merupakan zona bening yang terbentuk di sekitar kertas cakram karena tidak adanya pertumbuhan bakteri uji yang disebabkan karena terdapat zat atau senyawa antibakteri yang menghambat pertumbuhan bakteri uji pada sampel uji [15].

Tabel 3. Hasil rata-rata antibakteri (Hand Soap)

\begin{tabular}{lcccc}
\hline \multicolumn{2}{c}{ Hand Soap } & Kontrol & $\begin{array}{c}\text { Lidah } \\
\text { Buaya }\end{array}$ & $\begin{array}{l}\text { Daun } \\
\text { Sirih }\end{array}$ \\
\hline Total & 0.70 & 8.00 & 11.90 \\
\hline Rerata & 1.50 & 10.00 & 15.00 \\
\hline
\end{tabular}

*a-c Superscript huruf yang berbeda menunjukkan perbedaan nyata $(\mathrm{P}<0.05)$ dengan uji lanjut BNT

Pada penelitian ini, bakteri yang digunakan adalah Eschrichia Coli, dan didapatkan hasil dimana daya hambat/antibakteri Hand Soap ekstrak lidah buaya (Aloe vera) sebesar $9.12 \mathrm{~mm}$ dan Hand Soap ekstrak daun sirih (Piper betle Linn) sebesar $13.97 \mathrm{~mm}$, sedangkan untuk Hand Soap kontrol memiliki daya hambat paling kecil yaitu 1.29 mm. Menurut Davis dan Stout (1971), kriteria kekuatan dari daya antibakteri dikategorikan berdasarkan diameter zona hambatan yang terbentuk yaitu diameter zona hambatan $<5$ $\mathrm{mm}$ dikategorikan lemah, zona hambat 5-10 mm masuk dalam kategori sedang, sedangkan zona hambat 10-20 mm masuk dalam kategori kuat dan zona hambat $20 \mathrm{~mm}$ atau lebih masuk dalam kategori sangat kuat [17].

Berdasarkan diameter zona hambat, Hand Soap kontrol masuk dalam kategori lemah, Hand Soap ekstrak lidah buaya (Aloe vera) masuk dalam kategori sedang, sedangkan pada Hand Soap ekstrak daun sirih (Piper betle Linn) masuk dalam kategori kuat. Adapun hasil analisa statistik menunjukkan adanya perbedaan pengaruh secara signifikan, baik itu Hand Soap kontrol dengan Hand Soap lidah buaya, Hand Soap kontrol dengan Hand Soap daun sirih, maupun Hand Soap lidah buaya dengan Hand Soap daun sirih, dapat dilihat pada tabel 3. Perhitungan anova daya hambat bakteri sabun didapatkan bahwa Signifikansi $<0.05$ $(0.000<0.05)$, maka terdapat perbedaan yang nyata pada pengaruh ekstrak lidah buaya dan ekstrak daun sirih terhadap kualitas Hand Soap yang dihasilkan.

Adapun perbedaan hasil tersebut dikarenakan pada Hand Soap lidah buaya terdapat senyawa saponin, tannin, dan flavonoid yang berperan sebagai antibakteri [18]. Pada Hand Soap Daun sirih terdapat senyawa fenol dan turunannya yang dapat menghambat pertumbuhan bakteri [6]. Sedangkan pada Hand Soap kontrol menggunakan bahan sintetik yaitu Sodium Lauryl Sulfate (SLS) dan Triklosan, yang dimana triklosan adalah senyawa non-ionik yang biasanya digunakan sebagai bahan aktif sabun untuk membunuh bakteri [9] [19].

Pada pengujian tinggi busa didapatkan hasil semua produk memenuhi SNI. Berdasarkan standar SNI, syarat dari tinggi busa sabun cair adalah 13-220 mm. Hal ini dikarenakan bahan pembuatan sabun sendiri yang berperan sebagai surfaktan yaitu Sodium Lauryl Sulfat (SLS) yang berfungsi sebagai pengikat busa [20].

Tabel 4. Hasil rata-rata daya busa (Hand Soap)

\begin{tabular}{|c|c|c|c|c|}
\hline \multicolumn{2}{|c|}{ Hand Soap } & Kontrol & $\begin{array}{l}\text { Lidah } \\
\text { Buaya }\end{array}$ & $\begin{array}{l}\text { Daun } \\
\text { Sirih }\end{array}$ \\
\hline \multirow{4}{*}{ 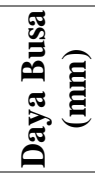 } & U1 & 2.50 & 2.80 & 2.70 \\
\hline & $\mathbf{U} 2$ & 2.90 & 2.80 & 2.80 \\
\hline & U3 & 2.60 & 2.70 & 2.80 \\
\hline & U4 & 2.50 & 2.70 & 2.80 \\
\hline \multicolumn{2}{|c|}{ Total } & 10.50 & 11.00 & 11.10 \\
\hline \multicolumn{2}{|c|}{ Rerata } & 2.62 & 2.75 & 2.77 \\
\hline
\end{tabular}

Rata-rata tinggi busa yang didapatkan pada masing-masing Hand Soap dapat dilihat pada tabel 4. Pada Hand Soap kontrol didapatkan tinggi busa sebesar $26.25 \mathrm{~mm}$, Hand Soap ekstrak lidah buaya (Aloe vera) sebesar $27.5 \mathrm{~mm}$, dan Hand Soap ekstrak daun sirih memiliki tinggi busa yang paling tinggi sebesar $27.75 \mathrm{~mm}$. tinggi busa dari ketiga Hand Soap memenuhi standar SNI yaitu 13$220 \mathrm{~mm}$. Adapun hasil analisa statistik perhitungan anova daya busa sabun didapatkan bahwa Signifikansi $>0.05(0.211>0.05)$ maka $\mathrm{H}_{0}$ diterima, jadi dapat disimpulkan bahwa tidak ada perbedaan pengaruh secara nyata antara Hand Soap 
ekstrak lidah buaya (Aloe vera) dengan Hand Soap ekstrak daun sirih (Piper betle Linn). Hal ini mungkin disebabkan karena konsentrasi pada asam stearate yang digunakan pada ketiga Hand Soap sama. Asam stearate berfungsi menghasilkan dan mempertahankan stabilitas sabun [21].

\section{KESIMPULAN}

Berdasarkan hasil penelitian dan pembahasan, dapat disimpulkan bahwa terdapat perbedaan pengaruh ekstrak lidah buaya (Aloe vera) dan daun sirih (Piper betle Linn) terhadap kualitas Hand Soap yang dihasilkan pada parameter $\mathrm{pH}$, viskositas dan antibakteri, sedangkan pada parameter organoleptik dan daya busa tidak terdapat perbedaan yang signifikan. Adapun berdasarkan data yang telah dianalisa dapat disimpulkan bahwa Hand Soap dengan ekstrak daun sirih memiliki kualitas yang lebih baik bila dibandingkan dengan Hand Soap kontrol dan Hand Soap lidah buaya dilihat dari viskositas, daya antibakteri dan daya busanya.

\section{DAFTAR PUSTAKA}

[1] Fazlisia, A., Bahar, E., \& Yulistini, Y. (2014). Uji Daya Hambat Sabun Cair Cuci Tangan pada Restoran Waralaba di Kota Padang Terhadap Pertumbuhan Bakteri Escherichia coli dan Staphylococcus aureus Secara In Vitro. Jurnal kesehatan andalas, 3(3), 348353.

[2] Melliawati, R. (2015). Escherichia coli dalam kehidupan manusia. BioTrends, 4(1), 10-14.

[3] Novyana, R. M., \& Susianti, S. (2016). Lidah Buaya (Aloe vera) untuk Penyembuhan Luka. Jurnal Majority, 5(4), 149-153.

[4] Suryati, N., Bahar, E., \& Ilmiawati, I. (2018). Uji Efektivitas antibakteri ekstrak aloe vera terhadap pertumbuhan Escherichia coli secara in vitro. Jurnal kesehatan Andalas, 6(3), 518522.

[5] Ariyanti, N. K., Darmayasa, I. B. G., \& Sudirga, S. K. (2012). Daya hambat ekstrak kulit daun lidah buaya (Aloe barbadensis Miller) terhadap pertumbuhan bakteri Staphylococcus aureus ATCC 25923 dan Escherichia coli ATCC 25922. Jurnal Biologi, 16(1), 1-4.

[6] Carolia, N., \& Noventi, W. (2016). The potential of green sirih leaf (Piper betle L.) for alternative therapy Acne vulgaris. Majority, 5(1), 140-145.

[7] Sari, R., \& Isadiartuti, D. (2006). Studi efektivitas sediaan gel antiseptik tangan ekstrak daun sirih (Piper betle Linn.). Majalah Farmasi Indonesia, 17(4), 163-169.

[8] Rahmi, Lale Suce Dwi. 2018. Pengaruh Komposisi Sodium Sulfat Terhadap Kualitas
Produk Sabun Cuci Tangan (Hand Soap) [Skripsi]. Mataram: FPMIPA IKIP Mataram.

[9] Gusviputri, A., PS, N. M., \& Indraswati, N. (2017). Pembuatan sabun dengan lidah buaya (aloe vera) sebagai antiseptik alami. Widya Teknik, 12(1), 11-21.

[10] Muharni, M., Fitrya, F., \& Sofa, F. (2017). Uji Aktivitas Antibakteri Ekstrak Etanol Tanaman Obat Suku Musi di Kabupaten Musi Banyuasin, Sumatera Selatan. Jurnal Kefarmasian Indonesia, 7(2), 127-135.

[11] Rosdiyawati, R. (2014). Uji Efektivitas Antibakteri Sediaan Sabun Mandi Cair Minyak Atsiri Kulit Buah Jeruk Pontianak (Citrus nobilis Lour. Var. microcarpa) terhadap Staphylococcus aureus dan Escherichia coli (Doctoral dissertation, Tanjungpura University).

[12]Pasir, S. (2014). Penyuluhan Dan Praktik Pembuatan Sabun Cuci Piringcair. Asian Journal of Innovation and Entrepreneurship, 3(03), 155-158.

[13] Widyasanti, A., Rahayu, A. Y., \& Zain, S. (2017). Pembuatan Sabun Cair Berbasis Virgin Coconut Oil (VCO) dengan Penambahan Minyak Melati (Jasminum Sambac) sebagai Essential Oil. Jurnal Teknotan, 11(2), 1-10.

[14] Sari, R., \& Ferdinan, A. (2018). Pengujian aktivitas antibakteri sabun cair dari ekstrak kulit daun lidah buaya. Pharmaceutical Sciences and Research (PSR), 4(3), 111-120.

[15] Mujadin, A., Jumianto, S., \& Puspitasari, R. L. (2015). Pengujian Kualitas Minyak Goreng Berulang Menggunakan Metoda Viskositas dan Perubahan Fisis. Jurnal Al-Azhar Indonesia Seri Sains dan Teknologi, 2(4), 229233.

[16] Sukawaty, Y., Warnida, H., \& Artha, A. V. (2016). Formulasi sediaan sabun mandi padat ekstrak etanol umbi bawang tiwai (Eleutherine bulbosa (mill.) Urb.). Media farmasi, 13(1), 14-22.

[17] Dimpudus, S. A. (2017). Formulasi sediaan sabun cair antiseptik ekstrak etanol bunga pacar air (Impatiens balsamina L.) dan uji efektivitasnya terhadap bakteri Staphylococcus aureus secara in vitro. PHARMACON, 6(3), 208-215.

[18] Suryati, N., Bahar, E., \& Ilmiawati, I. (2018). Uji Efektivitas antibakteri ekstrak aloe vera terhadap pertumbuhan Escherichia coli secara in vitro. Jurnal kesehatan Andalas, 6(3), 518522.

[19] Agusta, W. T. (2016). Optimasi Formula Sabun Cair Antibakteri Ekstrak Etanol Daun Sirih Merah (Piper Crocatum Ruiz \& Pav.) dengan Variasi Konsentrasi Virgin Coconut Oil (Vco) dan Kalium Hidroksida (Koh). 
Jurnal Mahasiswa Farmasi Fakultas Kedokteran UNTAN, 3(1), 1-16.

[20] Chastelyna, A. J., Supartono, S., \& Wijayati, N. (2017). Uji Aktivitas Antibakteri Sabun Cair Ekstrak Daun Jati (Tectona Grandis Lf). Indonesian Journal of Chemical Science, 6(1), 72-76.
[21] Sari, F. I. (2016). Uji Stabilitas Fisik dan Aktivitas Antibakteri Minyak Atsiri Pala (Myristica fragrans Houtt.) Terhadap Bakteri Staphylococcus aureus dalam Formulasi Sabun Cair. Naskah Publikasi. 